Article

\title{
Unexpected Convergences: Religious Nationalism in Israel and Turkey
}

\author{
Jocelyne Cesari ${ }^{1,2}$ \\ 1 Department of Theology and Religion, University of Birmingham, Birmingham B15 2TT, UK; \\ Jc2348@georgetown.edu \\ 2 Berkley Center for Religion, Peace and World Affairs, Georgetown University, 3307 M St NW, Suite 200, \\ Washington, DC 20007, USA
}

Received: 6 September 2018; Accepted: 13 October 2018; Published: 30 October 2018

check for updates

\begin{abstract}
This article compares Israel and Turkey to demonstrate how religious nationalism can be analyzed by a combination of historical institutionalism and conceptual history of religious ideas and doctrines. Both cases exemplify how the building of the nation-state was associated with the exportation of the western concept of religion. The resulting association between national territory, state and religion can explain the existing politicization of religion.
\end{abstract}

Keywords: nation-state; religion; historical institutionalism; secularization; conceptual history

\section{Introduction}

At first glance, comparing Israeli and Turkish nationalism seems a contrived exercise, like comparing apples and oranges. There is of course the precedent of Devji Faysal's book Muslim Zion (2013) that draws parallel between Israel and Pakistan. Since Pakistan was built as a Muslim nation, the analogy with Israel as a Jewish nation seems right or at least sensible. It is quite different to compare Israel and Turkey, which is often presented as the "only secular" Muslim country. So one may wonder: why carry on such an intriguing if not straight up foolish task?

For two main reasons. First, because Israel and Turkey exemplify how the building of the nation-state was associated with the exportation of the western concept of religion. Second, the resulting association between nation, state and religion can explain, in both cases, the politicization of religion. Of course, the building of nation-states has been widely studied in and outside Europe and North America (see Nasr 2001; El-Affendi 1991; Moore 1966; Skocpol 1979). Most of this previous research focuses on political institutions, or the specifics of nationalist ideologies. In a similar fashion, the western origin of the concept of religion has been analyzed (Asad 1993). However the conjunction of these two processes and their influence on the ongoing politicization of religion has not been explored. This is the current blind spot in the literature that this paper intends to illustrate.

In order to do this, I provide an "eclectic" (see Katzenstein and Sil 2010) methodology which combines historical institutionalism and conceptual history. In other words, the comparison between Israel and Turkey consists of an investigation of the religious and political concepts of nation, state, sovereignty and of an analysis of institution-building which relies, or reinforces these concepts.

\section{Theoretical Framework: Nation, State and Religion}

Most analyses treat religion as an empty or black box that has been manipulated by "clever" secular rulers. For example, Devji Faysal argues that for both Israel and Pakistan, the 'religion' they invoked bore little relation to 'the life world of belief and practice' (Devji 2013, p. 5). Religion was not 'some oldfashioned theological entity, but an abstract and modern idea of belonging' (Devji 2013, p. 47). In the case of Muslim nationalism, religion, namely, Islam, became no more than 'another aspect of the social 
contract $[\ldots]$ and even an empty idea [ ... ] deployed to name only the most general and disparate of qualities, like a theologically indeterminate belief in the God of Muhammad' (Devji 2013, p. 47).

I argue, however, that Islam and Judaism are not simply abstract, empty categories instrumentalized by the state. They are not simply beliefs or doctrines either. In fact they entail bodies of believers and clerics, buildings, imagination and emotions, all of which were deeply transformed by their recalibration within the nation-state framework.

My point is not to shed light on religion as a western construct. This has been done (Dubuisson 2003; Masuzawa 2005). It is also not about the challenges brought by the usage of Christian western categories to study non-Christian religions (Faur 2008; Dan 1998). In the same vein, Batnitzky (2013) has offered the ideational and political history of the forcing of Jewish traditions into the conceptual framework of religion.

What remains unexplored are the mutual interactions of religion and nation-state and how these interactions have contributed to the politicization of religion and the shaping of religious nationalism. In other words, the preconceived idea that modernity is based on a separation of religion and politics as distinct categories does prevent us from observing their inherent mutual influence. This is not to say that religion and politics interact only in modern times, but that it is only in modern times that their establishment as separate entities emerges as legitimate and synonymous of modernization. To say it differently, the underlying assumption that religion is or should be, apolitical is ironically inherently associated with the political legitimacy of the nation-state.

In this respect, I do not use the term "state" to refer to any form of political governance, but specifically to the hyphen of nation and state that emerged from the breakdown of Christendom at the end of the War of Religions and was then exported throughout the world via colonialism and trade. There is a tendency nowadays to loosely use the term 'state' to refer to political power, an example being referring to the "Ottoman state". Political power is indeed as ancient as humankind, but this does not mean that all forms of political power qualify as state. Historically, the state hyphenated with the nation is a modern construction that implies concentration and monopoly of the use of violence over a territory aligned with a population (defined by culture, language, or both). This type of political power emerged in Europe and became the international norm of political power with the collapse of empires and the decolonization processes.

Although exported, the nation-state is not simply a duplicate of the European ones. In fact, in most Muslim countries national identity was forged by state leaders through different procedures and religious and cultural choices, to the extent that it is more relevant to speak of a "state-nation" ${ }^{1}$ rather than "nation-state." The preeminence of the state can be observed throughout all nation-building processes, but what is specific to the colonial and postcolonial ones is the extremely rapid changes initiated by the state elites. There was no Turkish nation before the collapse of the Caliphate; it was literally created overnight by the sheer power of its nationalist rulers. New identities were forged in less than two generations and irremediably altered the relation of Turks to Islam.

In this case, the state preceded the nation which requires to rethink the nation-state dyad and the nature of nationalism. As prompted by Halliday (2013), nationalism refers to two distinct entities. First, it is a set of theories and ideologies forged by Enlightenment philosophers onward. Second, it is a series of investigation into concrete nation-building and identities that can take two opposite forms: a perennial one (Kohn 1965; Seton-Watson 1977) that states the primordial and unique features of a given national group across historical periods or a modernist (Anderson 2006; Gellner 2008) in which nations are seen as the product of industrial society, history a resource by which elites can mobilize support (Halliday 2013, p. 43; Rokkan 1988).This duality translates into a schizophrenic body of literature with on one hand, theories and political philosophy loosely connected (if connected at all) to historical and sociological investigations of national identities across countries.

1 Alfred Stepan and Juan Linz generalized the use of the term in their edited volume (Stepan et al. 2011). 
In this article, I attempt to reconcile these two thread by comparing individual histories of nationalism in the light of these general theories and test them against the "historical record" (Halliday 2013, p. 83).In this respect, my work is located within the broader scholarship that considers nationalism as the sum of memories, emotions, values that align the cultural and political identity of people with a certain territory and institutions that control this territory (Friedland 2002) ${ }^{2}$. As a consequence, religious nationalism cannot be apprehended as a mere alternative ideology to the secular national project. In my analysis, religious nationalism refers to the alignment of religious collectivity, political sovereignty, and territory. One can argue that the co-terminality of territoriality and religion is nothing new, as it can found in pre-modern groupings like tribes, in which territory, people and God line up (Hudson 1976). Nonetheless, religion in nationhood is different from pre-modern forms because it can be used as the foundation of identity for the majority group, as well as for the minorities. Even in the case of secular nationalism, which operates on the distinction between the nation and religions, religious communities do not completely separate from the national culture. For example, Britain and the Netherlands were both seen as Protestant nations until well into the nineteenth century, when Catholics were included in the nation (Van der Veer and Lehmann 1999). Similarly, the nationalist Bharatiya Janata Party (BJP) in India has consistently framed the nation as an ancient Hindu civilization, diminishing the significance of Muslim and Christian groups and concealing the fact that the contemporary state is actually a "product of imperial encounter" after Partition.

This alignment of a territory, a political sovereignty and a people has deeply transformed religious doctrines, identities and behaviors everywhere. By comparing Israel and Turkey, the specifics of the Mosaic revelation are to be accounted for. Anthropologists of religion have argued that all religions entail one or three of the following elements: message, people and territory (see Bilgrami 2016). With the Mosaic revelation, the three were associated in an unprecedented way: one God, one people, one territory. The Jewish tradition is based on the covenant between one God and a people who accept the revealed message and the territory that goes with it. With Christianity and Islam, the message and the people recipient of the message expanded while the territory became secondary, if not irrelevant. The Christian message concerns all human beings beyond Jews and the Promised Land. The message of the Prophet Mohammed is also deterritorialized. We can argue that under Muslim empires, the Ummah was once a territorialized concept but at the time it referred, as I shall explain below, to all the lands and peoples including non-Muslims under the authority of the Caliphs.

For each tradition, the evolution of belief, belonging and behavior shows convergences and similarities. No work to date has traced the genealogy of the intersections between these three dimensions of religion and the territory-people-sovereignty triad of nationhood. To provide such a comprehensive genealogy is beyond the scope of this article. My goal is to show the heuristic potential of such an approach to explain religious nationalism in different contexts.

I contend that:

1. On the collapse of the Ottoman Empire, the building of nation-states in Muslim lands led to an unprecedented tension between Islamic belonging and national belonging, hence making the nationalization of Islam a major political issue until now.

2. In the case of Israel, one can argue that indeed the territorialization was a given by revelation. However, the nation-state based on the principles of equality and popular sovereignty does not align with the revelation-based territory given to one people by God.

3. In both cases, the state has become a major agent in defining Jewishness and Muslimness.

In other words, for Muslim nations the challenge was, and still is, to subjugate transnational claims and adjust Islam to one people and one location. For Israel, the challenge has been to recalibrate

2 Sociologists have known for a long time that even suicide, the most individual and solitary choice a human being can make, varies greatly across countries. Happiness, too, follows national patterns (see Veenhoven 1991). Nationality even impinges upon our bodies; obesity levels vary greatly across countries, for example. 
the notion of people to fit into the national boundaries. In both cases, the state has become central to religiously-based political claims.

\section{Islam between National and Supra-National Belonging}

Nation-building in Muslim countries resulted in a decisive re-organization of the society-state-religion nexus unknown in premodern times, since under the caliphates, Islamic institutions and clerics were not subordinate to political power. Furthermore, according to most scholars, divisions of labor and hierarchies between temporal and spiritual authorities were fairly well established by the tenth century (Ināyat 1982; Lapidus 1988). While there were certainly "official" ulama working on behalf of political rulers and providing religious justification for their policies in medieval times, back then religious authorities and institutions were financially and organizationally independent from the political power. The Caliphs also acknowledged the cultural and religious diversity of the population, although it did not translate into an egalitarian legal and political status for all religions and ethnicities. The ummah was defined as the sum of the territories and populations under the Caliphate rule, hence encompassing an extensive distribution of ethnic, cultural, and linguistic groups, including Muslims, Christians, Jews, Zoroastrians, Baha'is, and Druzes. In the same vein, the concept of Dar Al Islam, forged by medieval Islamic scholars, and opposed to Dar Al Harb (abode of War), was not inherently territorial. As phrased by Parvin and Somer: "it was rather a legal construct that has a territorial dimension: it as the political expression of the Muslim community in which Islam is practiced and protected by a Muslim ruler. In the Dar Al Harb, Muslims may be able to practice Islam but they do not enjoy the protection of the ruler". Additionally, this protection of the Muslim rulers is extended to non-Muslim religious groups (Parvin and Sommer 1980).

Even though the Caliphate represented the original community, which follows the message of the Prophet Mohammad, in reality, its power was transformed by geography and historically evolved into a secular dynasty overseeing multiple ethnic and religious groups (Hourani 1962, p. 212).

The changes toward the building of state-nations were put in movement in the Ottoman Empire by two events, the 1798 expedition of Bonaparte in Egypt and the 1856 Treaty of Paris. The former event set the parameters for the never ending debate on Islam and modernity with the rise of modernist-reformist movement (Salafiyya), and pan-Islamism (a political project of social cohesion based on Islamic belonging). The latter event refers to the Ottoman Empire's symbolic inclusion in the Westphalian order when for the first time at the end of the Crimean War, an Ottoman representative was invited to the diplomatic negotiations. In the aftermath of this symbolic inclusion, three disparate factors contributed to the adoption in Muslim lands of the Westphalian State system in the first half of the twentieth century: the fall of imperial governments in the region; the rise of local nationalist movements in urban centers such as Cairo, Tunis, Baghdad, and Damascus; and the emergence of states with demarcated territorial boundaries that pursued self-interests and experienced hostile territorial disputes with neighboring states. Pro-Western, liberal "civilizationalism" also became the dominant paradigm of the Ottoman modernists and reformists, despite strong internal resistance against Western imperialism. This opposition stemmed from the population's objection to the Western critique that the Caliphate was not "civilized" enough to gain the loyalty of its Christian subjects. This resistance subsequently led to two different movements: pan-Islamism and pan-Arabism.

The ultimate objective of pan-Islamism was the political unity of Muslim population under Islam rather than race or nationality (Lee 1942). It was part and parcel of the broader 19th century reformist movement seeking modernization without westernization, as illustrated by Islamic thinkers such as Rachid Rida (1865-1935), Afghani (1839-1897) or Mohammed Abduh (1849-1905).

Pan-Arabism, on the other hand, recognized the cultural and linguistic affinity among Arabs and aimed to establish a single state for a united Arab nation (Reiser 1983). Despite divergent political goals, these two movements developed in close proximity in the last period of the Ottoman Empire and were both influenced by European political principles. 
Usually, the influence of western political concepts is acknowledged through the historical accounts of reforms in the Ottoman Empire that implemented constitutionalism and parliamentarism (see Karpat 2002). It would be misleading however to think that these reformists rejected Islam. In fact, the Young Turks, the predecessors of Kamal Ataturk (1881-1938), did not envision a secular regime; rather, they conceptualized shari'a as the foundation for reform and freedom (Riedler 2011, pp. 26-41; Hanioğlu 2010, pp. 103-4). The pinnacle of this movement's achievements, the Ottoman Constitution of 1876-which was modeled on the Belgian constitution of 1831—established an appointed upper house of parliament and an elected lower house with legislative authorities. This development signified a shift toward a civic Ottoman identity, but did not challenge the traditional structure of the political system. ${ }^{3}$

These political changes were paralleled by reformist religious thought-known as Salafiyya-although it is not proven that the term was endorsed as such by the modernists of the time (Lauzière 2016). Salafiyya, which takes the Salaf (early Companions of the Prophet Mohammed) as reference, has garnered confusing meanings because of its current use by the followers of Abd al-Wahhab's doctrine, or Wahhabism, which greatly differs in its orientation and goals from the modernist reformist movement of the 19th century (see Algar 2002; Fadl 2007). The former rejects the teachings of the four Sunni schools of jurisprudence or madahib and advocates the imitation of the Prophet Mohammed by emphasizing the Hadith (accounts of the words and deeds of the Prophet). The latter also rejects the consistent observance of the schools of jurisprudence but unlike Wahhabism, encourages new interpretations ${ }^{4}$. The reformist-modernist movement is understood as an attempt to resist the cultural influence of the West, and is therefore presented as the paragon for religious authenticity by turning inward to the Islamic heritage to compete with Western cultural input. For example, the Salafiyya entry in The Oxford Encyclopedia of the Modern Islamic World (Esposito 1995) in a typical fashion reads:

In its inception however, Salafiyya did not involve direct opposition to European imperial rule over Muslims. Rather, the intellectual figures of the movement saw it as internal Islamic reform to compete with the scientific and economic leadership of the West, through education and scholarship ${ }^{5}$.

What is often downplayed, is that this revivalism was actually deeply influenced by Western cultural and political concepts (Asad 2003). I have shown that under this influence, Islamic reformism irremediably changed the meanings of traditional concepts such as shari'a, ijtihad, ummah and jihad. Generally, it meant that the reformists rejected the methods of interpretation based on the clerics' consensus to allow more individual initiative, in a manner that can be compared to the Protestant Reform. By doing so, they deliberately altered the meaning of tradition (taqlid) which refers to a set of methodologies used by clerics to make the past relevant to the present. By adopting the modernist and positivist understanding of tradition, they redefined it as a fossilized knowledge that is not relevant to the present (Vikør 2006). They also politicized concepts that were the prerogative of clerics independent of the political power by conceiving their reformist work as a political response to the western domination. After the national independences, the capitation of Islam by the state solidified these political connotations of traditional concepts and made them "natural" to masses and clerics alike ${ }^{6}$. In the same vein, the modern vision of the ummah has been removed from this

3 For an evaluation of the Ottoman constitution and parliament see Devereux (1964); Brown and Sharif (2004, pp. 59-60); Shaw (1976, pp. 174-89, 213-14).

4 Scholars like Fadl (2007) have noted that with the international religious influence of the Saudi Kingdom, Wahhabism and Salafism have become synonymous, hence erasing the initial modernist connotations of the term.

5 See the Salafiyya entry in The Oxford Encyclopedia of Islam of the Modern Islamic World (2015) for the whole debate on the impossibility of the Islamic state or the nature of political Islam.

6 Therefore, debating the nature of political Islam in light of medieval concepts like those we are seeing in the debate on the Islamic nature of ISIS is moot. In fact, it is misleading to think that Islamists refer to the premodern meanings of shari'a or ijtihad when they use these terms. 
imperial definition; the consensus among Muslim scholars being that the ummah refers to a spiritual, non-territorial community distinguished by the shared beliefs of its members. The ummah is therefore seen as a type of citizenship that all Muslims possess independently of their territorial location, which was a major conceptual change brought about by pan-Islamism and the establishment of the ummah as a competitive political community aimed at superseding the nation (Hassan 2002, p. 94) . $^{7}$

As the Ottoman Empire collapsed, the emergence of the state as the central political institution went hand-in-hand with the homogenization of the populations inhabiting the nation's territory. That is why nation-building systematically omitted and sometimes eradicated particular ethnic, religious, and linguistic groups in order to create one nation defined by one religion and one language. This homogenization process also led to a politicized narrative of religion, i.e., political Islam.

With the rise of the nation-state, a congruence was created between Muslims of a certain obedience (for example, Maleki, Shafi'I, Hanbali and Hanafi schools) and bounded territory ${ }^{8}$.

In the case of Turkey, Kamal Ataturk considered that Islam has to be reformed and westernized in order to adjust to the national community. His main goal was to put Islam at the service of the nation-building and of good citizens. In other words, Islam was a major resource for the rulers to educate and socialize new "Turks" according to the needs of the Republic. Turkish secularization therefore never meant autonomy of religion. Interestingly, Ataturk, operating through the lens of European ideology, saw this secularization as a de-politicization of Islam by removing the social influence of Islamic rituals and leaders. In a move opposite to those of Zionists, rituals and practices of Islam were not central to the building of the public space and were recalibrated at the level of the individual-citizen. At the same time, belonging to Islam was key to the fashioning of the Turkish collective identity.

The founding charters of the Turkish Republic and the decisions of the Erzurum and Sivas conferences 9 constantly referred to those "Muslims who form one nation" or "all Islamic elements of the population"10. These charters hardly mentioned the "Turkish nation" as a separate entity and always include "Kurd" alongside "Turk." In other words, it was not a "Turkish" war of liberation, as claimed in the official historiography, but rather a war of "Muslim elements" to free the caliphate from the occupation" (Yavuz 2003, p. 45).

During the state building phase, Islamic institutions were deeply transformed by the appointment of laymen to positions previously held by clerics, as well as the integration of clerics into the state's administrative structure. At the same time, unlike most Muslim countries (and Israel), Turkish rulers eliminated Islamic provisions from family law in the 1930s, and the influence of shari'a on national law has since become residual ${ }^{11}$. In 1925, all religious movements and titles, such as sheikh, dervish, junger, tschelebi, occultist, magician, and mausoleum guard were abolished (Saeed 1994, p. 160). Furthermore, the office of the ŞeyhiulIslam - the mufti at the head of the Ottoman religious hierarchy-was closed (Earle 1925, p. 86). Religious property was nationalized under the Ministry of Religious Affairs and Pious Foundations, along with all other Islamic institutions. Madrasas (religious

7 For example, cleric Yusuf al-Qaradawi has declared: "I believe in the unity of the Muslim Nation with all its groups, sects and doctrines, since the entire ummah believes in one Book and one Messenger, and faces one qiblah (the direction that Muslims take when praying to face Kabah)." Furthermore, the existing difference between the ummah's various groups does not separate any of them from the Muslim body. The Hadith that refers to the division of the ummah into groups indicates that they all belong to the ummah (Al-Qaradawi 1996).

8 Within the Islamic tradition, there are four schools of jurisprudence-Hanafi, Shafi'i, Maliki, and Hanbali-all named after their respective founders. In the 9th and 10th century, these schools were consolidated and separated from the caliphal political power.

9 The Erzurum conference was held in the city of the same name by Turkish Revolutionaries from 23 July to 4 August 1919. Sivas Congress was held as an assembly of the Turkish National Movement from 4 to 11 September 1919 in Sivas.

10 Assembly of Turkish Revolutionaries and Turkish National Movement (1919) (Yavuz 2003, p. 45).

11 The 1926 Turkish Civil Code led to unity of the court system, replacing Mecelle, which was a code that employed Shari'a but was modeled after the 1912 Swiss civil code. The new law banned polygamy and gave equal rights to divorce. The current Turkish Civil Code reformed in 2001 is an updated version of the 1926 civil code, with an addition stating that family forms the basis for society and operates on equality between the spouses. 
schools) were integrated into the national education system (Earle 1925, p. 244). In 1930, religious education was removed from the curriculum. In 1997, eight years of education became compulsory for children, effectively delaying them from entering any religious schools and therefore only offering high school education as an option (Finkel 2012). All of these reforms simultaneously legitimized religion under state control while minimizing religious influence in politics (Findley 2010, p. 252). Islam was therefore deprived of its previous impact on social life but granted strong influence on the national Turkish community.

The creation of the Diyanet, or Ministry of Religious Affairs, cemented the institutional fusion of the state and Sunni Islam, which discriminates against people who belong to non-Sunni groups such as Alevis and Shiites ${ }^{12}$. The chairman of Ehli Beyt (Shia) Scholars Association, Kadir Akaras, told Al-Monitor, "Most Shiite branches in Turkey maintain an independent standing from the directorate because it is against our belief to be under the guidance of any state authority" (Tremblay 2013). On the other hand, the Turkish state does not recognize their place for gathering and worship officially (cemevi) nor offers subsidies, although members of the Alevi group have frequently requested and sought recognition.

The status of Islam in the state system could not be better exemplified than during failed coup against the Erdogan regime in July 2016. On July 15, Erdogan and Mehemet Gormez, the head of Diyanet, issued orders to all imams of the Turkish Republic to rally citizens to denounce the military coup. Sala prayers-which were traditionally read at the mosque to announce funerals, as well as during the Ottoman era to announce difficult times during the wars-were read overnight. Muharrem Ince, an opposition parliamentarian in the Republican People's Party, tweeted in response:

The call to prayer is not just a call to pray, but it is also a sign of our freedom, independence and our claim to this land. Same is true with the sala (prayer). But I cannot stand it anymore that the mosques have become the backyard of a political party (Tremblay 2016).

Generally speaking, the grafting of Islam onto state institutions and national identities has primarily taken place through three mechanisms: nationalization of Islamic institutions and clerics, incorporation of Islam into the legal system and inclusion of Islam into the national narrative taught in schools. The outcome of these three processes is what I have called hegemonic Islam (Cesari 2014).

Hegemonic Islam is a major break away from the modernization process of Europe, where the separation of the state authority from religious institutions and ideas was the crucial condition for modern citizenship. It is also worth noticing that despite their pan-Islamist origin, all Islamically-based political movements have adjusted to the national frame. Even if pan-Islamists were opposed to nationalism, they were also influenced by it-especially after decolonization, when the nation became the "natural" political space, instead of being perceived as "foreign" or Western. Thus, Islamist movements gradually used Islam more as an alternative to the secular nationalism promoted by state elites, and less as a way to promote the return of the Caliphate. In this sense, Islamist movements have increasingly operated within the context of the newly defined national political community.

For example, the Islamist opposition in Turkey\{ XE "Turkey" \} began as a peripheral movement, but grew into a series of political parties that came to dominate the political scene. The starting point for such an evolution was the establishment of a multiparty system in 1946. Subsequently, as early as 1950, the Democratic Party, which was much more lenient towards Islamic values, started to re-legitimize Islam in the public and political spheres (Rabasa and Larrabee 2008, p. 36). The more liberal policies of the Democratic Party throughout the 1950s and 1960s ultimately set the stage for

12 The Diyanet, which stands for the Presidency of Religious Affairs, was founded on 3 May 1924 as part of the Turkish constitution. Its main objective is "to execute the works concerning the beliefs, worship, and ethics of Islam, enlighten the public about their religion, and administer the sacred worshiping places". It is responsible for drafting sermons that are delivered in mosques both in Turkey and abroad. It trains imams and teaches children Quranic education (see Diyanet İşleri Başkanliği 2016). 
the rise of Islamist parties. In the 1970s, Necmettin Erbakan (1926-2011) ${ }^{13}$, who would later become Prime Minister, merged several Islamist factions to create the Milli (National Vision or National View) movement (Rabasa and Larrabee 2008, p. 31). This movement ultimately produced Order Party (MNP) in 1970, later replaced by the National Salvation Party (MSP) in 1972. After its banning by the 1980 military coup, the MSP reemerged as the Welfare Party in 1983. These three parties ultimately gave rise to the current Islamist party in Turkey, the Justice and Development Party (AKP) \{ XE "Justice and Development Party (AKP)" \}. The leaders of these former parties promoted a new economic and social order that was based on "national/Islamic" principles, and their main goal was to restore a national Islamic order as an end to the Westernization process, which they saw as corrupt (Rabasa and Larrabee 2008, p. 40).

After Turkey's economic crisis, Recep Tayyip Erdogan\{ XE "Erdogan, Recep Tayyip" $\}$ of the AKP formed a single-party government, taking over as Prime Minister in 2003 after his party won the 2002 elections. Before the ascent of this "mildly" Islamist party into power, the secular parties such as the Republican People's Party and the Democratic Left Party dominated the Turkish government ${ }^{14}$. For the last decade, however, the AKP has been the dominant party and Erdogan a popular political figure despite its turn toward authoritarianism (Ozatay and Sak 2002; Waldman and Caliskan 2017, pp. 83-118; Bekdil 2017).

The AKP is often described a "conservative democratic party", rather than an Islamist one, which is a clear break from previous "Islamist" parties, that openly advocated for an Islamic stage. Furthermore, the AKP has worked within the framework of the Turkish national identity and utilized secularism \{ XE "secularization:secularism" \} in a way that enhances its legitimacy as a democratic party, while at the same time maintaining a culturally Islamic façade. Instead of opposing Western political values as other Islamic parties did in the past, the AKP has embraced Western ideas, and has even promoted more liberal market policies that have helped turn the country's economy around (Rabasa and Larrabee 2008, p. 48). The authoritarian turn of Erdogan regime since 2016 has led to a more assertive Islamic rhetoric and some political reforms but has not yet significantly undermine the Kemalist state culture.

\section{Zion vs. Nation}

Interestingly, although the westernization of Judaism started in the same time period as the westernization of Islam, the presence of Jews in European nations meant that this westernization took a different path. Despite the diasporic conditions in which the Jews found themselves after the destruction of the second temple (70CE), the alignment between the message, the people and the territory remained engrained in the Jewish narrative and consciousness, in part because of their segregation from European pre-modern societies. However, the rise of nation-states created a tension between belonging to the Jewish people and to the territory given by God. As noted by Batnitzky (2013), from the 18th century onward, in order to fit Judaism into the new western concept of politics, the theological work of major religious and intellectual figures was to depoliticize the Jewish tradition and to focus on privatization. This de-politicization meant to downplay the notions of collective belonging to a people and allegiance to a land outside the nation of residence, hence ushering Judaism into modernity. As a result of these efforts, Jews began to disassociate their sense of collective belonging from the exilic consciousness, and to instead identify with secular national communities. As a result,

13 Erbakan was a Turkish engineer and politician who published the ideology of the National View Movement in a 1969 manifesto titled Milli Görüş. He was also the first Islamist Prime Minister of Turkey in 1996 before he was deposed by the military soft coup in 1997.

14 The Republican People's Party is the official Kemalist Party in Turkey, and since Ataturk's\{ XE "Ataturk, Mustafa Kemal" \} rule, the party has been mostly comprised of secular elite and pro-Western members. The Democratic Left Party (DLP) was formed in 1985 by Rahsan Ecevit, who was the wife of Bulent Ecevit, a former Prime Minister banned after the 1980 coup. Bulent Ecevit later won the election in 1999 under the DLP and became Turkey's Prime Minister once again. The party was officially declared a social-democratic party, and was also affiliated with Kemalist ideology. 
Judaism as a modern religion became less about the survival and resilience of religious community and much more about individual practices and conformity to religious law (halakha).

In this respect, Moses Mendelsohn (1729-1786) as the founder of the Haskala (Englightenment) was a key religious figure in the depoliticization of Judaism. He observed a diversification of Jews in different denominations of practice; some were Liberal, some were Reform, and some were Orthodox. According to his thought, each of these groups, including Orthodoxy, is predicated on the basis that Judaism and politics are kept separate. He claimed that its understanding of Judaism is rational, not coercive, because it is driven by the heart and mind rather than by external pressures (Batnitzky 2013). Even Orthodoxy, is predicated on the basis that Judaism and politics are kept separate. These theological transformations were accelerated by the political emancipation of Jewish communities throughout Europe in the 18th and 19th centuries.

In 1785, amidst renewed debate surrounding the appropriate treatment of Jews in France Jews were given permission to settle in all parts of France and the poll tax imposed on them was abolished. It is, however, the French revolution that precipitated the emancipation of Jews with support of political figures such as the Comte de Clermont-Tonnerre (1747-1792) and the Abbe Gregoire (1750-1831), who famously exclaimed that the Republic had to grant everything to Jews as individual citizens and nothing as a community (Philippe 1979). In 1790, however only the Avignonese and the Portuguese Jews had been declared full citizens, but this small victory fueled hope of emancipation among the wider Jewish community, and on 27 September 1791, the proposition that French Jews should be entitled to the rights of full French citizens was enthusiastically adopted by the Assembly. Thus the Jews were given individual rights within the state, but these rights were not predicated on their Jewishness, but rather on the necessary equality of all citizens independent of their religion or race (although not yet their gender).

Along the same lines, Napoleon (1769-1821) established in 1806 a representative body for the Jewish community, the Consistoire, which has survived until now. He also recognized Judaism as an official religion of France in 1807. After the Restoration, the condition of French Jews continued to improve, and in 1831, they were granted full equality with no restricted access to universities, political offices, finance, and the arts.

Most significantly, with the imperialist ambitions of Napoleon, the idea of emancipation of the Jews slowly spread throughout Europe. The Frankfurt Parliament granted Jewish emancipation during the Revolutions of 1848 after declaring that religious faith did not predicate the right to civil rights. Some German states did not implement this decision right away, although other states like Hanover and Prussia had already awarded Jews citizenship. While those emancipated did not face legal discrimination, they continued to face societal discrimination within Germany in areas such as employment. On 3 July 1869, the North German Federation forced the remaining German states denying Jews their rights to emancipate them. Further pressure was put on them to do so when they joined the new unified German state in 1871.

The rise of Zionism complicated the perceived divide between the Jewish religion and politics because it expressly argued against the depoliticization of Judaism in favor of a Jewish nation. Interestingly, the Zionist concept of the 'nation' is similar to the western one, the emergence of which caused the need for a depoliticization of Judaism in the first place. Like Mendelsohn, Theodore Herzl (1860-1904), the father of modern Zionism, operated on the distinction between religion and politics, but unlike Mendelsohn, he emphasized the latter over the former. He envisioned a Jewish nation-state which would provide political independence and sovereignty to the Jewish people but did not have to embody "religious" ideas and values.

The Zionist movement was in fact divided on the status of the "Jewish religion" in the new nation-state. One group, led by Ahad Ha'am's (1856-1927) saw Judaism as culture. Using the European empiricism and positivism of Locke, Hume, Mill, and Spencer, Ha'am reinterpreted the Jewish tradition. In a similar fashion to the Salafis discussed above but with different results, Ha'am internalized the idea that tradition is the past, and hence religious practices belong to the past and 
Judaism had to undergo secularization through reform. At the same time, these traditions had to be maintained, not for personal salvation or spirituality, but as the "cultural" features of the nation. In his view, a "national theology" was needed which means that the moral and ethical mission of the Jews inscribed in the covenant with God are transferred to the mundane nation. As a result, personal belief in God becomes irrelevant while religious practices become the rituals of the new political community in order to build a nation, establishing Judaism as a political culture.

By contrast, the second group of Zionist ideologues, influenced by Nietzsche and represented by intellectual figures like Berdyczweski (1865-1921), rejected religious practices altogether to focus only on the historical identity of Jews built by oppression. In other words, as Sartre said more than a century later, a Jew is defined by the external eye and centuries of persecution (Sartre 1985). In this view, there is no place for the practices of Judaism as political culture. In line with western conception of citizenship, the individual, not the religious community, is the cornerstone of the modern nation. In similar and more radical ways, socialist-Zionists like Nachman Syrkin (1868-1924), Itshak El Azari Volcani (1880-1955) or Yosef Haim Brenner (1881-1921) proposed to replace the religious tradition with the socialist and Zionist ideology as a new religion in order to transform disparate groups of immigrants into a new nation. This confrontational model with the religious tradition, was emblematic of the political leaders who came from eastern-Europe to Palestine in the beginning of the 20th century and founded the state of Israel in 1947.

The new state was built on the impossible synthesis of these two conflicting conceptions. The Jewish identity of the state was the only feature these two groups could agree on, as determined by the United Nations Partition Plan (Knesset 1947) as well as by the Declaration of the Establishment of the State of Israel (1948), and by two Basic Laws dealing with human rights-Section iA of Hok Yesod: Kevod Ha-Adam Ve-Heruto [Basic Law: Human Dignity and Liberty], Section 2 of Hok Yesod: Hofesh Ha-Issuk [Basic Law: Freedom of Occupation].

Since the 1967 Six Days war, religious messianism as expressed by Rabbi Abraham Yitzhak Kook (1865-1935) has risen as a significant movement which presents the particularity of locating messianic claims within the boundaries of the secular nation-state. Often coined as religious-Zionism, the movement combines allegiance to the holy land and the state. It therefore breaks the delicate synthesis attempted by the "founding fathers" in order to emphasize not only orthopraxis but also religious sanctity of the land. In this perspective, the state (and not only individual Jews) has to abide by this sanctity. If it does not, its politics are considered heretical and delaying messianic times (Yadgar, Yaacov 2017, p. 152).

Because of this impossible balance between secular nation and religious ideal, there has been no consensus of what Jewish means, hence fueling ongoing political disputes up to this dayCase in point, on 18th and 19th July of 2018, the members of the Knesset, passed a new Basic Law that defined Israel 'as the Nation-State of the Jewish People'. The law states that Israel "is the historical homeland of the Jewish people ... in which it fulfills its natural, cultural, religious and historical right to self-determination ... The right to exercise national self-determination in the State of Israel is unique to the Jewish people". As such, one clause of the bill states Israel will also act as a sanctuary to Jewish people 'in exile', not only those resident in it, as it "will strive to ensure the safety of the members of the Jewish people in trouble or in captivity due to the fact of their Jewishness or their citizenship". As Basic Law, it acts like Israel's constitution, guiding its legal system. It is therefore afforded an element of immutability, as it can only be amended by the passing of another Basic Law (Wootliff 2018). The bill has raised concerns because it does not mention the rights of individuals or non-Jewish groups (unlike the 1947 declaration). It is seen as increasing the risk for discrimination of non-Jews and segregation between Jews and non-Jews. Israel's Arab community expressed outrage, with for example Arab lawmaker, Ayman Odeh, calling the law one of "Jewish supremacy" which left Arabs as "second-class citizens". The law's declaration of Jerusalem as the capital of the country and of Hebrew as the official language added to the controversy although Prime Minister, Benjamin Netanyahu, attempted to reinsure Arabs by asserting: "122 years after Herzl made his vision known, 
with this law we determined the founding principle of our existence. Israel is the nation state of the Jewish people, and respects the rights of all of its citizens" (Lis and Landau 2018).

Generally speaking, since independence, the tensions between orthodox religious groups and the secular elite have been prevented to politically escalate by the implicit agreement on what is known in Israeli politics as "the status quo". This refers to the agreement between Ben Gurion (1886-1973) and the representatives of the Haredi (i.e., ultra-Orthodox) community in 1947. This agreement preserved the arrangements previously existing under the British Mandate and inherited from the Ottoman Empire, which allowed the different religious communities to operate their own legal systems in the sphere of personal status law. The agreement went further than the law, since it exempted Torah students from military service and assured that they would receive a small stipend to study the Torah full time even after marriage and until the age of 40. It was a deal struck by the leadership of a largely secularized Ashkenazi pioneering elite steeped in European ideas, who were convinced that the development of the modern Jewish nation would soon render orthodox groups obsolete.

The status quo, by shaping Judaism as national culture however challenges the traditional theories of secularization. Religious holidays (Passover, Yom Kippur, New Year, Sukkot) are national holidays but do not require religious practices or beliefs from citizens, leading to a distinction between orthodox Jews (or in Hebrew, as 'religious Jews') and secular Jews. The national allegiance to Israel is what connects and unifies these disparate categories of citizens. Therefore discussion about whether Judaism constitutes a religion or a nationality relentlessly pervades Israeli politics. On one hand, Jewish laws and practices have built the national identity, yet on the other hand, these practices are continuously critiqued for not allowing the emancipation of the individual.

In the words of Amnon Rubinstein, 'the secular law has subjected Jews to the jurisdiction of the rabbinical courts ... [and] if religious freedom means freedom from religion it exists in Israel only to a limited degree'. Although he recognized that 'there is no established religion in the ordinary sense', he noted, with a touch of disapproval if not irritation, that 'within Judaism the law only recognizes the orthodox community and grants a monopoly to orthodox institutions' which 'have jurisdiction in personal status and exclusive jurisdiction in marriage and divorce' (Rubinstein 1967).

Unlike Turkey or other Muslim countries, the state of Israel did not absorb Jewish institutions into the state system and as such religious minorities are recognized. The state grants them official status and confers governmental powers on them. The best illustration of these modes of establishment is the monopoly granted by the state of Israel to the non-Jewish religious communities, empowering them to adjudicate in all aspects of personal law, a monopoly that is identical to that vested in the rabbinate regarding all aspects of marriage and divorce in the Jewish community.

Religion is established by the state in three ways; providing funds for it (budgeting), granting it governmental powers (authority), and giving it official status. In Israel, Jewish and non-Jewish religious communities are afforded all three. The courts of both the Muslim and Druze communities, like the Rabbinical Court, have official status and are considered part of the state's legal system. While Christian community courts are not part of the state's official legal system, under law, including the "Religious Courts Law", they have judicial authority identical to that of other communities and religious courts. Under Articles 51-54 of the Palestine Order in Council, issues of personal status, marriage and divorce are subject to the religious law of an each individual's religion, with authority on these issues coming from the religious court of the relevant community. Recent years have however, seen the Supreme Court and legislative branch of the state become more involved in these issues and reducing the jurisdiction of religious courts, especially within the Muslim community (although Sharia courts still have more authority than the courts of all other religious groups). With regards to budgeting, the state pays the salaries of judges in religious courts. In addition, it supports religious minorities by providing funds for religious needs. Under the legal obligation for funding religious needs equitably (based on the relative size of the religious group), when funding for a Jewish practice is allotted, the same amount of funding must be allotted to other religious groups for their counterpart practices. This is even considered the case where a counterpart practice does not exist in another 
religion, as shown by a ruling from the Supreme Court in 2000 declaring that the Ministry of Labor and Social Affairs had been discriminatory by funding support for the Jewish needy before Passover, (in line with the Jewish custom of kimcha d'Pischa), while not doing the same for the Arab needy despite no Muslim counterpart practice existing ${ }^{15}$. As a result, the Ministry amended its criteria for supporting needy families at the time of Jewish religious holidays so they would also apply to those of other religions. However the gap between legal equality and political discrimination of non-Jewish religious groups is a continuous topic of contention (Sapir and Statman 2015, pp. 74-75).

The gap between law and political practice also affects religious minorities in the domain of education. The State of Israel confers a high degree of autonomy on the Jewish ultra-Orthodox educational system as part of the "recognized but not official" path, and it has also established an official state education- al system for the benefit of religious Jews who are not ultra-Orthodox.42 Similar options are not available to Christian or Muslim citizens who wish to provide a religious education for their children. In contrast to the official religious educational system for Jews, the state has not established a non-Jewish religious educational system that would provide religious education for Christians or Muslims. The only option open to non-Jewish parents who wish to provide religious education for their children is to send them to private schools, and indeed many of them do so, but at significant expense.

\section{Who Is a National, Who Is a Citizen?}

As a result of this institutional entanglement between religious and national belonging, the definition of who is a national and who is a citizen is also a major religious topic. Additionally, because the centrality of the state in defining religious legitimacy, political and religious practices significantly overlap.

This nationalization of Islam is the implicit principle shared by both the "secular" and Islamists in most Muslim countries. In other words, the conflation between national territory and Islamic belonging is not contested by most of their citizens, except the minorities groups. In Turkey, the inclusion of information regarding a person's religious identity on Turkish identity cards were in part designed to ensure the Lausanne Treaty of 1923 could be implemented. The treaty granted non-Muslim minorities within the country special self-governance rights. However, the inclusion of religion on the cards also acted as "important symbolic elements of the newly-manufactured Turkish identity", under which, (though this would be disputed officially), Turkish nationality was associated with being Muslim. Non-Muslims were entitled to Turkish citizenship but not nationality. The Alevis, a Shia group in Turkey, were one group opposing the inclusion of religious identity on the identity cards. They did so on the grounds that it required individuals to disclose their religious beliefs, and that they were classified as part of Islam due to the state's consideration of Alevism as a Muslim sect. As some Alevis consider their tradition separate from Islam, this designation was argued to restrict their religious freedom. Alevi organizations, including the European Confederation of Alevi Associations (ECAA) and the Alevi-Bektasi Federation (ABF), took action to eliminate the religious designation from the ID cards (Esen and Gonenç 2008, pp. 579, 582-83, 586). In 2016, The Turkish Parliament decided to remove the religious affiliation component on Turkish identification cards, although it may still be registered on the electronic chips on cards. (MacDonald 2016).

Along the same line, under the Law of Return, introduced in 1950, Jews, their spouses, and their descendants are allowed to migrate to Israel, although this law does not automatically afford them Israeli citizenship. The criteria under which an individual is considered a citizen of Israel is set out in the Israeli Nationality Law of 1952, which has been subject to amendments since its introduction. Generally, the primary criteria for Israeli citizenship is jus sanguinis, or citizenship by descent, as opposed to jus soli, which is citizenship by place of birth. The permanent residency status can be

\footnotetext{
15 For details of the case, see (Versa 2014a).
} 
held by residents of Israel who are not citizens, and this is commonly the form of civil status held by residents of East Jerusalem and the Golan Heights.

For those who are not entitled to citizenship by descent, citizenship might be acquired through the process of naturalization, the requirements of which are residency in Israel for three out of the previous five years and the right to reside in Israel on a permanent basis. In 2003, under the Citizenship and Entry into Israel Law, naturalization was suspended for citizens from a number of countries, these individuals being termed "enemy nationals" by some. The validity of the law was upheld in a January 2012 case at the Supreme Court of Israel.

According to Israel's population registry, who is considered a Jew is determined by religion and grant automatically nationality and citizenship. Nationality and citizenship are distinct, yet religion and nationality are considered identical as the state grants citizenship to those who are defined and identified as Jews and this understanding also regulates immigration laws and the law of return. However, those with Israeli nationality do not also have to claim to belong to the Jewish nation, but this does not work inversely. In the 1972 case of Tamarin $v$. the State of Israel (The Nabka Files 2018) heard at the Supreme Court, Tamarin, who was listed as of Jewish nationality but as of no religion, argued for his right to be registered as of Israeli nationality. However, the court denied his request in line with mainstream Zionist ideology, demonstrating Israel's inability to decipher the meaning of being a Jewish state as the court had ruled in favor of Jewishness rather than of a Hebrew nation. This was reiterated more recently in a similar ruling in 2013 (Versa 2014b). Thus, it is technically not possible to be Hebrew by nationality and of no religion.

Additionally, Israeliness and Jewishness are synonymous in political culture. This also raises questions over the status of Arab Israelis, who are considered the 'other' in the Israeli nation-state and are confined to minority status. The lack of consistency with nationality status is also demonstrated by the different status afforded to non-Jewish immigrants (for example, from Russia) who become Jewish by entering the ethno-national community, again playing into the idea of synonymy of Israeliness and Jewishness. But tensions arise when these ethnic Jews cannot marry according to Israeli civil law that is based on the orthodox definition of a Jew as someone born from a Jewish mother.

\section{Contested Religious Behaving}

Because of this embedded connection between state and religion, the religious behaviors in public space are sites of contestation by both secular and religious groups.

According to the Pew Research Center, Israel places "high" levels of restriction on religion (Pew Research Center 2009). Such restrictions include limits placed on non-Orthodox Jews as illustrated in the highly mediatized case known as the Women of the Wall. The Rabbi of the Western Wall or Kotel has enforced gender segregation, limitations on the religious garb that can be worn by women, and prohibited g women from carrying the Torah. While the "Women of the Wall" observe gender segregation during services so Orthodox women can fully participate, their use of religious garb usually reserved to men (kippah, prayer shawls, tefilins), singing and reading from the Torah, have led to violent confrontations with orthodox men and arrests. The May 2013 ruling of the Israeli Supreme Court established however that the Women of the Wall gatherings are not illegal, and that they instead had been misinterpreted. Women of the Wall (which has been constituted in a multidenominational feminist organization) welcomed the Israeli Cabinet's approval of a plan that designated a new space at the Western Wall which would not be under Rabbinate control and available for egalitarian prayer. However, the plan faced opposition from other groups, including members of the Israeli Prime Minister's governing coalition, who are ultra-Orthodox. The Supreme Court ruled in January 2017, that if the Israeli government could not find reason for the prohibition of women reading the Torah in prayer services at the Western Wall within thirty days, the prohibition would be overturned. The petition demanding the overturning of the prohibition was brought by the 'Original Women of the Wall', a group who split from Women on the Wall. The 2016 arrangement has been suspended 
and tensions are still lingering. Women who wear the prayer shawl can be subject to police control (although the number of arrests has decreased).

Along the same line, tensions between secular and Islamists have fueled Turkish politics since the 1980s. The ban on Islamic attire in public institutions such as government ministries and public institutions led to clashes, most notably the 1998 confrontation between police and students at Istanbul University after authorities refused to allow women wearing headscarves to take their final exams. In September of the same year, the university issued regulations from the new semester that forbade Islamic-style beards for men and headscarves for women. Protests against such regulations were cited as the motivation for the hijacking of a Turkish Airlines plane travelling from Ankara to Istanbul, as well as the November 1998 Islamist demonstration in Istanbul (Gruen 1999). When the AKP came to power in 1997, the tensions on dress code were inverted, meaning that the claims were now carried by secular women who were concerned by the risk of imposing the headscarf to all female citizens (Gole 2004).

During the 2007 campaigning of the Islamist Abdullah Gul to the presidency, the Kemalist political elite raised concerns about his wife wearing a headscarf if she were to become first lady. When Gul did win the election, his wife was continuously criticized by the kemalists for "tarnishing" the secular image of the country (Elver 2014).

The tensions about dress code also take place in the school system. In 2012, under President Erdogan, the Education Ministry argued that the uniforms children had been required to wear in school were old-fashioned and thus acted in opposition to modern education. They were discarded as a result. At the same time, a new regulation allowed female students in middle and high public schools to wear the headscarf full-time despite their counterparts in non-Muslim schools not being able to wear the headscarf in Qur'an classes. The government also lifted the ban on women wearing the headscarf in higher education (2008) (although the law banning it officially remains in place) (Jones and Goktas 2008).

In general, the school system remains a continuous site of competition between Islamists and secularists. In 2012, the AKP government implemented a series of courses in Sunni Islam, both mandatory and elective, to supplement education on religious culture and morals, a move which was seen in the context of a larger shift towards religious education. Another change toward Islamization, has been the government's plan to restructure the education system from an eight-year primary school and a four-year high school stages to a system based on three four-year periods of duration (which the media have termed " $4+4+4$ "), the likely reason for this change being that it allows parents to put their children in religious schools earlier, as before all children had to attend largely secular schools for eight years before they could switch to a different school. Thus, religious education could be revitalized through the changes, especially with the addition of an integrated religious education system offered from the fifth grade.

Along the same lines, in October 2017, the Turkish parliament, dominated by the AK Party, passed a new law which allows religious civil servants to perform civil marriages. The implementation is purportedly designed to cut the number of unregistered marriages in Turkey, as religious ceremonies are not always legally binding, but has been criticized for undermining secularism by replacing civil marriage with religious marriage (Uras 2017).

Another domain of contestation common to Israel and Turkey concerns public morality and sexual minorities. The legal tolerance of homosexuality but not of same sex marriage in Israeli law is tempered by societal hostility, comparable to the one experienced by the same groups in Turkey. When it became a state in 1948, Israel had inherited British Palestine's penal code, which included an anti-sodomy law. Although Israel did not strike down the sodomy law until 1988, the law hadn't been applied at least as far back as 1953, when Israel's Attorney General considered the law obsolete and instructed law enforcement authorities to ignore it. His successors did the same. An uneasy equilibrium took effect. The authorities would try not to pay attention to gay people, and gay people wouldn't draw too much attention to themselves. It was an early version of "Don't ask, don't tell." 
Since the repeal, Israel has adopted generally progressive measures on GLBT rights. In 1992, the Knesset amended its ban on anti-discrimination at work to include sexual orientation. A series of legal cases expanded GLBT rights in economic and personal affairs, such as inheritance and adoption. Israel was one of the first countries to allow openly gay men and women to serve in the military, a policy shift that came about in 1993, and the army has been a symbol of the integration of GLBT Israelis into mainstream society. Israel's experience with gay integration in the military was even held up as a positive example during the debate over repealing “Don't ask, don't tell" in the U.S.

Although same sex marriages are not legal, they can be recognized when performed abroad. Different kind of domestic partnership, which is really de facto marriage, entitles a couple to most of the rights and benefits of marriage. Israel has no equivalent of the American Defense of Marriage Act (DOMA), which disallows federal tax (and other) benefits. Indeed, Israeli same-sex couples could claim tax breaks even before the court ordered that they be allowed to register as married.

Homosexuality was decriminalized in 1858 as part of the ottoman reforms. It has continued to be legal since the founding of modern Turkey in 1923. Turkey was the first Muslim-majority country to hold a gay pride march. Since 2003 and 2008 respectively, they have been held annually in Istanbul and Ankara with increasing participation (more than 15,000 attended the parades in 2011 and 2012). However, while under the Geneva Convention LGBT people have the right to seek asylum in Turkey since 1951, same-sex couples do not have the same legal protections as their heterosexual counterparts. Since 1988, transsexual people have had the right to change their legal gender. In the public context, opinion on homosexuality is generally conservative and LGBT experience discrimination, harassment, and violence. While they have been debated legally, protections against discrimination on the basis of gender identity or expression and sexual orientation have not yet been introduced into legislation. The 2013 Constitutional Reconciliation Commission's draft of the new constitution of the Republic agreed to provide protection against LGBT discrimination, but the draft was later cancelled. However, on 17 July 2014, a ruling by Turkey's Supreme Court stated that referring to gay people as "perverted" constitutes hate speech.

To sum up, in Israel, the religious and national belonging is at the core of the rise of religious parties and figures who claim the upper hand to define who is a citizen based on religious criteria. More broadly it is continuous source of tensions with Muslim and Christian Arabs and more recently Druzes (with the 2018 Basic Law). In Turkey, the tensions are less about the belonging and more on the religious behaving and its alignment with the public space and civic behaviors.

In both cases, theological and teleological dimensions are conferred on the nation-state. The state emerges at the very heart of Jewish existence, as the only agent instilling a meaningful content into the "Jewish" collectivity and enabling it to remain a cohesive people. Moreover the collectivity centered on the state supersedes all other Jewish communities (Yadgar, Yaacov 2017, pp. 71-72). In this regard, a statist Jewishness or Muslimness is at play. It means that most Israelis or Turks maintain religious practices as allegiance to the state, not to a revelation-based community, and hence comply with a religious calendar as cultural practice. Jewishness has even its intellectuals who promote the state political theology, like A.B Yehoshua (b. 1936), who considers the Jewish Israeli as wholly, opposed to the Jew in diaspora who is only a "partial Jew" (Blumenfeld 2012).

In the case of Turkey, or most Muslim nation-states for this matter, the statist Muslimness has been increasingly challenged by transnational revivalist groups like the Güllen movement, which led to the aborted military coup of July 2016 and the subsequent crush of Gulenist followers by the Erdogan regime, as well as its rebranding by the state as the "Fethullah Güllen Terror Organization (FETO)". According to Yavuz and Koç, even by previous coup standards, the systematic repression of gulenist insitutions and individuals constitute the most extensive purge in the history of the Turkish Republic (Yavuz and Koç 2016). The Gulen movement started in the 1980s as an educational initiative on campuses, to gradually morph into a global religious movement steeped in secrecy. It enjoyed a good relationship with the AKP when the latter came to power in 2002, with the appointment of Gulenists to key government positions in order to counter the secularist resistance of some segments 
of the state system. As time went on, the political control by Gulenists over key security establihments created a wedge in the partnership with the AKP, highlighting the divergence of interests between the two and leading ultimately to the failed military coup of 2016. Even before the coup, this conflict had become so imprinted on Turkey's wider political landscape that any criticism of the government was labelled 'Gülenist' (Yavuz and Koç 2016). A similar international challenge also comes from groups that call for the return to the caliphate in violent ways like ISIS or the rise of the Combatant Ummah like Al Qaida; a situation that is beyond the scope of this paper (Cesari 2018).

\section{Sovereignty from God to State}

In Turkey and Israel, the modern political power has reordered the immanent and transcendent axes and altered the concept of God's sovereignty.

To be clear the immanent/transcendent arose before the nation-state. It is constitutive of what is usually called the axial age, which refers to the rise of Judaism, Christianity, Islam and Buddhism which order cosmos and human kind along two axes: on one hand, the transcendent referring to a reality above humans and on the other hand, the immanent, which is the domain of human life. In the case of Christianity, Taylor (2007) has shown how with the rise of state and national communities, immanent became increasingly regulated within and by the nation-state to which all believers must pay allegiance. In other words, the rise of the nation-state displaced Christianity from its claim over both the transcendent and immanent, by giving the state the upper hand on the latter, hence confining God's sovereignty to the guidance of human souls and not anymore to the mundane fate of political communities. The Western understanding of the secular builds on this separation. It affirms, in effect, that the "lower" immanent or secular order is all that there is, and that the "higher", or transcendent, order does not exist to regulate the "lower". The believers in the transcendent are therefore expected to keep it to themselves and not let belief influence the political or social practices in which they are engaged. This separation was accelerated through the Reformation, laying the groundwork for the ascendance of a neutral, self-sufficient secular order, and leading to the contemporary situation where belief in God is considered to be one among several viable spiritual options.

If we turn to the political development outside the west, this article shows that the division of labor between the state as regulator of the immanent, and religion as the domain of the transcendent, which was the outcome of European history, was exported everywhere with the diffusion of the nation-state through colonization, trade, and wars. In this respect, Judaism and Islam, have been redefined in the national contexts to become "modern" religions (Batnitzky 2013; Cesari 2014). The major shift brought by the modern political order has been the preeminence given to the individual salvation over the revelation-based community although as we have seen such a preeminence remains an acute site of contestation. It has nevertheless deeply transformed theological debates and doctrines. In other words, like Christianity in Europe at the time of the Reform, Judaism and Islam have seen not only their political and social influence, but also their doctrinal content redefined to make room for state sovereignty over mundane matters and limit God's sovereignty to the guidance of souls.

\section{Conclusions}

The particularity of religious nationalism does not lie in the fact that the nation-state redefined the rules of engagement between religion and politics, which happened everywhere, including in secular countries like France or the $\mathrm{UK}^{16}$. What is specific to both Israel and Turkey (or most of Muslim states for this matter) is the construction of Islam and Judaism as national cultures. It does not simply mean that religious rituals are part of the national calendar which is also the case in secular countries. More

16 For example, in France, which is typically presented as the paradigm of political modernization associated with the disappearance of religion, the Jacobin phase of the French Revolution and its accompanying "Cult of Reason" went beyond the notion of "civil religion" as defined by Rousseau (see Greenfeld 1993). 
importantly, it is that civic and national belonging are tied to religious belonging and hence enforceable by law. It therefore undermines the religious and ethnic plurality of society, not because religious groups or ideas are resilient to modernity. It is in fact quite the opposite in the sense that modernization of religion and building of nation-state became intertwined. The emergence of new political norms tied to nationalism resulted in state narratives that either referenced religious terminology or were diversely articulated within a religious framework. Religious references and norms were used to "localize" the nation-building process and legitimize state actors and policies. The outcome of such localization was the redefinition of Islam and Judaism within the new state institutions. This redefinition of religion by the nation-state also happened in Europe and the USA but the outcome has been the rise of religious pluralism while what we describe in this article is a religious homogenization which impinges on intra and inter religious diversity.

For this reason, it would be misleading to read such a situation as the public return of religion or the end of secular revolutions as some scholars have claimed (Walzer 2015). To apprehend religious nationalism we want to go back to Durkheim, the founding father of secular sociology, who emphasized that the symbolic presence of the divine is integral to the construction of the social—an insight that was somewhat lost in the modernization of Europe but has much relevance to political Islam or Judaism. Durkheim's insight sheds light on the fact that Islamic and Jewish symbols, concepts, and institutions have been integral to the constitution of modern political orders. From this perspective, political institutions do not merely appropriate, cooperate, or instrumentalize religion; they redefine it as part of the new social and political order. Religious nationalism becomes the collective identity innate to each individual, and submission to the new political system extends from this individualism. Religious nationalism is not simply the use by the state of Islam or Judaism for political control. Rather, it is a trait of the new psyche of citizens under the new political order, embodied in automatic behaviors inculcated since childhood. Such a mentality is not simply the outcome of an ideological transformation, but also a material one illustrated by the creation of new religious institutions embedded in the state apparatus.

To capture this continuous interactions between religion and politics, I decided to explore the changes of religious ideas and political institutions as a never ending process which requires a combination of historical institutionalism and conceptual history. My hope is that such a method could be relevant to other cases of religious nationalism beyond the scope of this article.

Funding: This research received no external funding.

Conflicts of Interest: The author declares no conflict of interest.

\section{References}

Algar, Hamid. 2002. Wahhabism: A Critical Essay. North Aledon: Islamic Publications International, ISBN 9781889999135.

Al-Qaradawi, Yusuf. 1996. Al Ummah al Islamiyyah: haqigah la wahm [An Islamic Ummah: Reality Not Fantasy]. Translated by Ahmad Nuryadi Asmawi. Selangor: Thinker's Library.

Anderson, Benedict. 2006. Imagine Communities: Reflections on the Origin and Spread of Nationalism. London: Verso, ISBN 9781844670864.

Asad, Talal. 1993. Genealogies of Religion: Discipline and Reasons of Power in Christianity and Islam. Baltimore: Johns Hopkins University Press, ISBN 9780801846328.

Asad, Talal. 2003. Formations of the Secular: Christianity, Islam, Modernity. Stanford: Stanford University Press, ISBN 9780804747684.

Batnitzky, Leora. 2013. How Judaism Became a Religion: An Introduction to Modern Jewish Thought. Princeton: Princeton University Press, ISBN 9780691160139.

Bekdil, Burak. 2017. Turkey's Slide into Authoritarianism. Middle East Quarterly 24: 1-9.

Bilgrami, Akeel, ed. 2016. Beyond the Secular West. New York: Columbia University Press, ISBN 9780321170802.

Blumenfeld, Revital. 2012. A.B. Yehoshua: Americans, Unlike Israelis, Are Only Partial Jews. Haaretz. March 18. Available online: https:/ / www.haaretz.com/1.5206064 (accessed on 11 August 2018). 
Brown, Nathan, and Adel Omar Sharif. 2004. Inscribing the Islamic Shari'a in Arab Constitutional Law. In Islamic Law and the Challenges of Modernity. Edited by Yvonne Yazbeck Haddad and Barbara Freyer Stowasser. Walnut Creek: Altamira, ISBN 9780759106710.

Cesari, Jocelyne. 2014. The Awakening of Muslim Democracy: Religion, Modernity, and the State. New York: Cambridge University Press, ISBN 9781107664821.

Cesari, Jocelyne. 2018. What is Political Islam? Boulder: Lynne Rienner Publishers, ISBN 9781626376292.

Dan, Joseph. 1998. The Christian Kabbalah: Jewish Mystical Books and Their Christian Interpreters. Cambridge: Houghton Library of the Harvard College Library, ISBN 9780914630197.

Devereux, Robert. 1964. The First Ottoman Constitutional Period: A Study of the Midhat Constitution and Parliament. Baltimore: Johns Hopkins University Press, ISBN 9780801801600.

Devji, Faysal. 2013. Muslim Zion: Pakistan as a Political Idea. Cambridge: Harvard University Press, ISBN 9780674072671.

Diyanet İşleri Başkanliği. 2016. Diyanet İşleri Başkanliği. Available online: http://www.diyanet.gov.tr/en/home (accessed on 4 January 2017).

Dubuisson, Daniel. 2003. The Western Construction of Religion: Myths, Knowledge, and Ideology. Translated by William Sayers. Baltimore: Johns Hopkins University Press, ISBN 9780801873201.

Earle, Edward Mead. 1925. The New Constitution of Turkey. Political Science Quarterly 40: 73-100. [CrossRef]

El-Affendi, Abdelwahab. 1991. Who Needs an Islamic State? London: Grey Seal, ISBN 9781856400220.

Elver, Hilal. 2014. Turkey's first ladies and the headscarf controversy. Al Jazeera. September 20. Available online: https:/ / www.aljazeera.com/indepth/opinion/2014/09/turkey-first-ladies-headscarf-2014911114226379736.html (accessed on 24 July 2018).

Esen, Selin, and Levent Gonenç. 2008. Religious Information on Identity Cards: A Turkish Debate. Journal of Law and Religion 23: 579-603. [CrossRef]

Esposito, John Louis, ed. 1995. The Oxford Encyclopedia of the Modern Islamic World. Oxford: Oxford University Press, vol. 4, ISBN 9780195096156.

Fadl, Khaled Abu El. 2007. The Great Theft: Wrestling Islam from the Extremists. New York: Harper, ISBN 9780061189036.

Faur, Jose. 2008. The Horizontal Society: Understanding the Covenant and Alphabetic Judaism. Brighton: Academic Studies Press, vol. 2, ISBN 9781934843130.

Findley, Carter Vaughn. 2010. Turkey, Islam, Nationalism, and Modernity: A History. New Haven: Yale University Press, ISBN 9780300152616.

Finkel, Andrew. 2012. What's $4+4+4$ ? International Herald Tribune. March 23 . Available online: https:/ / latitude.blogs.nytimes.com/2012/03/23/turkeys-education-reform-bill-is-about-playingpolitics-with-pedagogy/ (accessed on 14 July 2012).

Friedland, Roger. 2002. Money, Sex, and God: The Erotic Logic of Religious Nationalism. Sociological Theory 20: 381-425. [CrossRef]

Gellner, Ernest. 2008. Nations and Nationalism. Ithaca: Cornell University Press, ISBN 9780801475009.

Gole, Nilufer. 2004. 'Islamisme et féminisme en Turquie: regards croisés'. In Le Foulard Islamique en Questions. Edited by Charlotte Nordmann. Paris: Éditions Amsterdam, ISBN 9782915547009.

Greenfeld, Liah. 1993. Nationalism: Five Roads to Modernity. Boston: Harvard University Press, ISBN 9780674603196.

Gruen, George E. 1999. Defining Limits on Religious Expression in Public Institutions: The Turkish Crisis over Headscarves. Jerusalem: Jerusalem Center for Public Affairs, Available online: http:/ /jcpa.org/article/defining-limits-onreligious-expression-in-public-institutions-the-turkish-crisis-over-headscarves/ (accessed on 24 July 2018).

Halliday, Fred. 2013. Nation and Religion in the Middle East. London: Saki, ISBN 9780863567193.

Hanioğlu, M. Sukuru. 2010. A Brief History of the Late Ottoman Empire. Princeton: Princeton University Press, ISBN 9780691146179.

Hassan, Riaz. 2002. Faithlines: Muslim Conceptions of Islam and Society. Karachi: Oxford University Press, ISBN 9780195799309.

Hourani, Albert Habib. 1962. Arabic Thought in the Liberal Age: 1798-1939. London: Oxford University Press.

Hudson, Charles. 1976. The Southeastern Indians. Knoxville: University of Tennessee Press, ISBN 9780870492488.

Ināyat, Hamid. 1982. Modern Islamic Political Thought. Austin: University of Texas Press, ISBN 9789839154153. 
Jones, Gareth, and Hidir Goktas. 2008. Turkish parliament lifts university headscarf ban. Reuters. February 9. Available online: https://www.reuters.com/article/us-turkey-headscarf/turk-parliamentdebates-headscarf-secularists-rally-idUSL0967026720080209 (accessed on 14 August 2018).

Karpat, Kemal Hasim. 2002. The Politicization of Islam: Reconstructing Identity, State, Faith, and Community in the Late Ottoman State. Oxford: Oxford University Press, ISBN 9780195165432.

Katzenstein, Peter, and Rudra Sil. 2010. Beyond Paradigms: Analytical Eclectism in the Study of World Politics. New York: Palgrave Macmillan, ISBN 9780230207967.

Knesset. 1947. UN General Assembly Resolution 18r (Partition Plan). Knesset. Available online: http:/ / www. knesset.gov.i[/process/docs/uni8i-eng.htm (accessed on 11 August 2018).

Kohn, Hans. 1965. Nationalism: Its Meaning and History, rev. ed. Malabar: Krieger Publishing Company, ISBN 9780898744792.

Lapidus, Ira M. 1988. A History of Islamic Societies. Cambridge: Cambridge University Press, ISBN 9780521779333.

Lauzière, Henri. 2016. The Making of Salafism: Islamic Reform in the Twentieth Century. New York: Columbia University Press, ISBN 9780231175500.

Lee, Dwight E. 1942. The Origins of Pan-Islamism. The American Historical Review 47: 278-87. [CrossRef]

Lis, Jonathan, and Noa Landau. 2018. Israel Passes Controversial Jewish Nation-state Bill After Stormy Debate. Haaretz. July 19. Available online: https://www.haaretz.com/israel-news/israel-passes-controversialnation-state-bill-1.6291048 (accessed on 23 July 2018).

MacDonald, Alex. 2016. Turkey ditches religion from IDs as it eyes EU membership. Middle East Eye. February 17. Available online: https:/ / www.middleeasteye.net/news/religion-be-left-new-identification-cards-turkey326099214 (accessed on 14 August 2018).

Masuzawa, Tomoko. 2005. The Invention of World Religions. Chicago: The University of Chicago Press, ISBN 9780226509891.

Moore, Barrington. 1966. Social Origins of Dictatorship and Democracy: Lord and Peasant in the Making of the Modern World. Boston: Beacon Press, ISBN 9780807050736.

Nasr, Vali Reza. 2001. Islamic Leviathan: Islam and the Making of State Power. Oxford: Oxford University Press, ISBN 9780195144260.

Ozatay, Fatih, and Guven Sak. 2002. The 2000-2001 Financial Crisis in Turkey. Washington: Brookings Institute, Available online: https://www.researchgate.net/publication/242034963_THE_2000-2001_FINANCIAL_ CRISIS_IN_TURKEY (accessed on 16 July 2018).

Parvin, Manoucher, and Maurie Sommer. 1980. Dar al-Islam: The Evolution of Muslim Territoriality and Its Implication for Conflict Resolution in the Middle East. International Journal of Middle East Studies 11: 1-21. [CrossRef]

Pew Research Center. 2009. Global Restrictions on Religion. Pew Forum on Religion \& Public Life. Available online: http: / www.pewforum.org/files/2009/12/restrictions-fullreport.pdf (accessed on 24 July 2018).

Philippe, Beatrice. 1979. Etre juif dans la société française du Moyen Age à nos jours. Paris: Montalba, ISBN 9782870276723.

Rabasa, Angel, and F. Stephen Larrabee. 2008. The Rise of Political Islam in Turkey. Santa Monica: RAND National Defense Research Institute, ISBN 9780833044570.

Reiser, Stewart. 1983. Pan-Arabism Revisted. Middle East Journal 37: 218-33. [CrossRef]

Riedler, Florian. 2011. Opposition and Legitimacy in the Ottoman Empire: Conspiracies and Political Cultures. Abingdon: Routledge, ISBN 9780415580441.

Rokkan, Stein. 1988. Dimensions of State Formation and Nation-Building: A Possible Paradigm. In The Formation of Nation States in Western Europe. Edited by C. Tilly. Princeton: Princeton University Press, ISBN 9780691007724.

Rubinstein, Amnon. 1967. State and Religion in Israel. Journal of Contemporary History 2: 107-21. [CrossRef]

Saeed, Javaid. 1994. Islam and Modernization: A Comparative Analysis of Pakistan, Egypt, and Turkey. Westport: Praegar Publishers, ISBN 9780275945664.

Sapir, Gideon, and Daniel Statman. 2015. Minority Religions in Israel. Journal of Law and Religion 30: 65-79. [CrossRef]

Sartre, Jean Paul. 1985. Réflexions sur la question juive. London: Folio Essais, ISBN 9782070322879.

Seton-Watson, Hugh. 1977. Nations and States: An Enquiry into the Origins of Nation and the Politics of Nationalism. London: Routledge, ISBN 9780891582274. 
Shaw, Stanford Jay. 1976. History of the Ottoman Empire and Modern Turkey. Cambridge: Cambridge University Press, ISBN 9780521291637.

Skocpol, Theda. 1979. States and Social Revolutions: A Comparative Analysis of France, Russia, and China. Cambridge: Cambridge University Press, ISBN 9780521294997.

Stepan, Alfred, Juan J. Linz, and Yogandra Yogandra. 2011. Crafting State-Nations, India and Other Multinational Democracies. Baltimore: Johns Hopkins University, ISBN 9780801897245.

Taylor, Charles. 2007. A Secular Age. Cambridge: Harvard University Press, ISBN 9780674026766.

The Nabka Files. 2018. Tamarin v. State of Israel (CA 630/70). Available online: http://nakbafiles.org/nakbacasebook/tamarin-v-state-of-israel-ca-63070/ (accessed on 24 July 2018).

Tremblay, Pinar. 2016. How Erdogan Used the Power of the Mosques Against Coup Attempt. Al-Monitor. July 25. Available online: http:/ / www.al-monitor.com/pulse/originals/2016/07/turkey-coup-attempt-erdoganmosques.html (accessed on 10 August 2016).

Tremblay, Pinar. 2013. Turkish Alevis Refuse Sunnification. Al-Monitor. September 11. Available online: http:/ / www.al-monitor.com/pulse/originals/2013/09/turkey-shiites-alevis-sunnification-gulenmosque-cemevi.html (accessed on 2 January 2017).

Uras, Umut. 2017. Turkey: Religious officials to perform civil marriages. Al Jazeera. October 20. Available online: https://www.aljazeera.com/news/2017/10/turkey-religion-officials-perform-civil-marriages171019132948431.html (accessed on 2 August 2018).

Van der Veer, Peter, and Hartmut Lehmann. 1999. Nation and Religion: Perspectives on Europe and Asia. Princeton: Princeton University Press, ISBN 9780691012322.

Veenhoven, Ruut. 1991. Is happiness relative? Social Indicators Research 24: 1-34. [CrossRef]

Versa. 2014a. Adalah Legal Center for Arab Minority Rights in Israel v. Minister of Religious Affairs. Versa. Available online: http:/ / versa.cardozo.yu.edu/opinions/adalah-legal-center-arab-minority-rights-israelv-minister-religious-affairs (accessed on 22 August 2018).

Versa. 2014b. Ornan v. Ministry of the Interior. Versa. Available online: http:/ /versa.cardozo.yu.edu/opinions / ornan-v-ministry-interior (accessed on 24 July 2018).

Vikør, Knut S. 2006. Between God and the Sultan: A History of Islamic Law. Oxford: Oxford University Press, ISBN 9780195223989.

Waldman, Simon, and Emre Caliskan. 2017. The New Turkey and Its Discontents. Oxford: Oxford University Press, ISBN 9781849045667.

Walzer, Michael. 2015. The Paradox of Liberation: Secular Revolutions and Religious Counterrevolutions. New Haven: Yale University Press, ISBN 9780300223637.

Wootliff, Raoul. 2018. Final text of Jewish nation-state law, approved by the Knesset early on July 19. The Times of Israel. July 18. Available online: https:/ / www.timesofisrael.com/final-text-of-jewish-nation-state-bill-setto-become-law / (accessed on 23 July 2018).

Yadgar, Yaacov. 2017. Sovereign Jews: Israel, Zionism, and Judaism. Albany: SUNY, ISBN 9781438465333.

Yavuz, M. Hakan. 2003. Islamic Political Identity in Turkey. New York: Oxford University Press, ISBN 9780195188233.

Yavuz, M. Hakan, and Rasim Koç. 2016. The Turkish Coup Attempt: The Gülen Movement vs. the State. Washington: Middle East Policy Council, vol. XXIII(4), Available online: https:/ /www.mepc.org/journal/turkish-coupattempt-gulen-movement-vs-state (accessed on 10 October 2018).

(C) 2018 by the author. Licensee MDPI, Basel, Switzerland. This article is an open access article distributed under the terms and conditions of the Creative Commons Attribution (CC BY) license (http:/ / creativecommons.org/licenses/by/4.0/). 